University of Rhode Island

DigitalCommons@URI

Open Access Master's Theses

1979

\title{
The Massachusetts Approach to Regional Resource Recovery
}

Kenneth Blumberg

University of Rhode Island

Follow this and additional works at: https://digitalcommons.uri.edu/theses

\section{Recommended Citation}

Blumberg, Kenneth, "The Massachusetts Approach to Regional Resource Recovery" (1979). Open Access Master's Theses. Paper 616.

https://digitalcommons.uri.edu/theses/616

This Thesis is brought to you for free and open access by DigitalCommons@URI. It has been accepted for inclusion in Open Access Master's Theses by an authorized administrator of DigitalCommons@URI. For more information, please contact digitalcommons-group@uri.edu. 
THE MASSACHUSEITS APPROACH TO REGIONAL RESOURCE RECOVERY

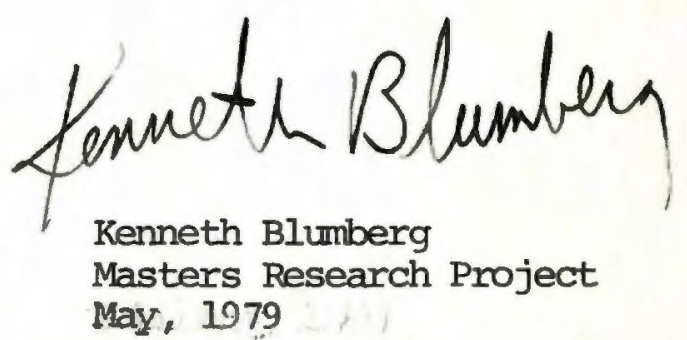


Master of Community Planning

Thesis Project

of

Kenneth Blumberg

Approved: $\frac{\text { Riad G. Mo hayni }}{\text { Major Professor }}$

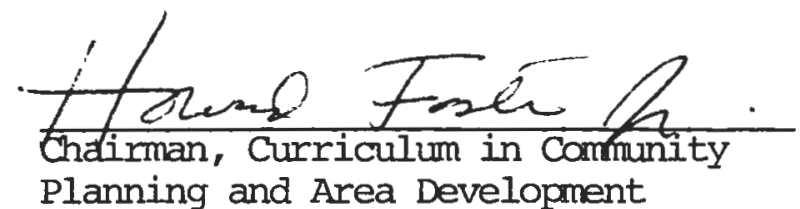

University of Rhode Island

1979 
Contents

Chapter I. Solid Waste Disposal and Recovery . . . . . . . . . . I A. Scope and Perception of the Problem ............... . . .

1. Growth in Municipal Solid Waste Generation . . . . . . 2

2. Ecological and Public Health Damages from Disposal . . . 3

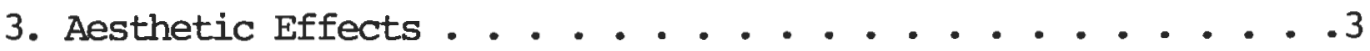

4. Broader Environmental Implications . . . . . . . . . 4

5. Solid Waste Disposal as an Index of Natural Resource

Depletion . . . . 5

6. Direct Costs of Collection and Disposal . . . . . . . . 5

7. Public Administration Problems . . . . . . . . . 5

B. An Approach to Solving the Scilid Waste Disposal Problem Resource Recovery . 6

C. How this Study is Organized . . . . . . . . . . . 7

Chapter II. Solid Waste Policy and Planning in Massachusetts . . . . . . 9

A. Initial Attempts to Create a Regional Approach . . . . . . .9

1. The Raytheon Report . . . . . . . . . . . . . 9

2. Mandatory Regions and Home Rule . . . . . . . . . 10

B. Voluntary Regionalization . . . . . . . . . . . . . 14

1. Legislation . . . . . . . . . . . . 14

2. The Massachusetts Solid Waste Plan of 1975 . . . . . . .

C. Current Regional Solid Waste Policy . . . . . . . . . 16

1. The 1977 Plan Update . . . . . . . . . . . . . 16

2. Towards Implementation - The 128 West Resource Recovery 
Chapter III. Regional Resource Recovery: A Background and Discussion. • . 20

A. Current Solid Waste Disposal Practices and their Costs . . . 20

B. An Alternative to Land Disposal . . . . . . . . . . 24

1. Resource Recovery . . . . . . . . . . . . . . 24

2. Inpacts of Resource Recovery Systems . . . . . . . . . 27

C. Regional Approaches to Solid Waste Management . . . . . . 30

1. The Need for Regional Organization . . . . . . . . 30

2. Theoretical and Practical Constraints on Regional

Organization . . 31

3. The Advantages and Disadvantages of Delocalized Approaches to Solid Waste Management . 33

4. Requirements for a Sound Approach to Regional Resource Recovery . . . 38

Chapter IV. The 128 West Resource Recovery Council: An Example of the Massachusetts Approach to Regional Solid Waste

Disposal . . 39

A. The Organization and Progress of 128 WRRC . . . . . . . 39

1. Events Leading to Implementation . . . . . . . . . 39

2. Site Selection . . . . . . . . . . . . . . 42

3. Political Difficulties in Siting Resource Recovery

Facilities . 44

4. The Request for Proposals . . . . . . . . . . . 47

B. An Evaluation of the 128 WRRC . . . . . . . . . . . 53

1. Organizational Framework .. . . . . . . . . 53

2. Appropriate Level of Organization . . . . . . . 54

3. Avoidance of a Single Mission Authority . . . . . . 55

4. Summary of the Advantages and Disadvantages of a Delocalized Approach . . 56 
iii.

C. Criticism of the Commonwealth of Massachusetts Approach . . 59

1. Role of the State ........................ 60

2. Local Technical Capacity ............ 63

3. The Bargaining Process ... . . . . . . . 65

4. Impacts and compensation . . . . . . . . . . 67

Chapter V. Conclusions . . . . . . . . . . . . . . 72

1. The Massachusetts Approach . . . . . . . . . 72

2. Recommendations . . . . . . . . . . . . 75 
CHAPTER I

SOLID WASTE DISPOSAI AND RECOVERY

A. Scope'and Perception of the Problem

The Environmental Protection Agency (EPA) has estimated that 140 million tons of solid waste are generated annually in the United States by both household and commerical sources. About six percent of this post-consumer municipal waste is recovered for productive uses.* The remaining $94 \%$ of this material is the cause of an increasingly critical solid waste disposal problem.

That portion of solid waste which is not recovered may be disposed of in any of several other more or less acceptable ways. At best, disposal can take place in environmentally sound landfills or incinerators. Such facilities, however, are usually the exception rather than the rule. It is more often the case that landfills are poorly designed or badly managed or both. Incinerators have been closed down throughout the country due to air pollution problems.

In Massachusetts eighteen incinerators have been closed because they did not comply with air pollution regulations. Only 200 of an estimated 350 landfills in the Commonwealth meet standards set by the Department of Environmental Quality Engineering (DEQE). Many landfills, both in and out of compliance with $\mathrm{DEQE}$ regulations, are reaching capacity. Communities throughout the Commonwealth are faced with critical decisions about what to do with their solid wastes in light of stricter environmental regulations, rising costs, and decreasing land availability.**

\footnotetext{
*U.S. Environmental Protection Agency. Resource Recovery and Waste Reduction Fourth Report to Congress. EPA Publication SW-600. Washington U.S. Government Printing Office, 1977. Page 1.

**eommonwealth of Massachusetts State Solid Waste Plan, September 30, 1977.
} 
Awareness of solid waste disposal as a major environmental and resource management issue was at a relatively low level until fairly recently. Quite possibly this has been due to non-recognition on the part of the public, government, and the private sector of the relationship of solid waste to the national energy and materials streams as well as to general pollution control. Solid waste is a less obvious and less directly irritating form of pollution than are liquid or gaseous wastes.*

The majority of the public's concern with solid waste disposal begins and ends with local rubbish pick-up or their weekly trip to the town dump. Afterwards it is both out of sight and out of mind. Local governments, until recently, did not regard solid waste disposal as a serious problem as long as they could accomplish it relatively cheaply in environmentally questionable disposal facilities.

The EPA's Resource Recovery and Waste Reduction Fourth Report to Congress lists seven reasons for the increasing national concern with the solid waste problem (here summarized and paraphrased):

1. Growth in Municipal Solid Waste Generation. More than two-thirds of residential and commerical solid waste is composed of manufactured products and packaging materials (the other third is composed of sewage sludge, junked autos and demolition wastes). It is estimated that these wastes have more than doubled since 1950. Thus, the sheer magnitude of post-consumer wastes has

\footnotetext{
*John E. Bryson, "Solid Waste and Resource Recovery" in Federal Environmental Law ed. Erica L. Dolgin and Thomas G. P. Guilbert, St. Paul, West Publishing Co. 1974.
} 
increased public awareness because of its influence on associated economic, social, and environmental problems.

2. Ecological and Public Health Damages from Disposal. Traditionally public health concern regarding solid waste focused on incinerator emmissions and insect and rodent control at collection, storage, and dump sites. Increasingly, however, this concern has broadened to include the contamination of surface and groundwater due to both surface runoff and underground leachates from landfills. This is particularly serious since it may rule out an aquifer as a source of drinking water for decades. The growing awareness of the need to protect water quality has significant economic implications. The cost of adequate leachate control at new landfills is expected to more than double the cost of disposal at these facilities.

3. Aesthetic Effects. Tens of millions of dollars are spent in the United States by local and state governments on street and highway litter pickups. The Commonwealth of Massachusetts, in 1975, spent about $\$ 3.5$ million for litter cleanup, $(\$ 1,185,000$. for cleanup of state highways and rest areas, \$285,000 for cleanup of state forest and parks, and $\$ 2,000,000$ for cleanup of Metropolitan District Commission highways, parks, and beaches.) These figures do not include the costs of local litter removal and street sweeping.* 
Although such figures may be an inadequate proxy of society's willingness to pay for an more pleasing aestheticaly environment, it does indicate that a significant value is placed upon the aesthetic quality of the environment.

4. Broader Environmental Implications. An increasing amount of consumer goods in this country are single-use throw away items. Very little of these goods are recycled. As a result, there is a large and growing flow of wastes. This systems of material flows can be characterized as a "high-throughput" economy. Virgin material extraction and initial raw material refining and processing are the largest source of environmental damage in this country. These activities also consume a disportionately high amount of energy. In contrast waste reduction approaches (such as the use of recyclable beverage containers, producing more durable products, and reducing amounts of packaging material) produce comparatively small amounts of adverse environmental impact while significantly reducing the amounts of wastes generated. In addition, technologies which recover energy and materials create less environmental damage and require less energy consumption than their virgin-materialutilizing conterparts.

Actions taken to reduce material throughput and recover post-consumer residuals will thus generally yield environmental protection benefits throughout the economic system and not only at municipal 
solid waste sites. In effect, this represents substitution of low-polluting systems for highpolluting systems of production and consumption.*

5. Solid Waste Disposal as an Index of Natural Resource Depletion. An economy which has a high amount of waste and a relatively small amount of material and energy recovery implies a high rate of virgin material consumption. A greater reliance on resource recovery would obviously conserve non-renewable resources.

6. Direct Costs of Collection and Disposal. The direct cost of collecting and disposing of an average ton:of municipal solid waste in 1976. was estimated by the EPA to be about $\$ 30.00$. For the U.S. as a whole the cost was nearly $\$ 4$ billion per year. It is thought that these costs doubled over the six to eight years prior to 1976. There are several reasons for these sharply rising costs: general inflation, growth of the waste steam, rising land values, longer hauls to increasingly more distant disposal sites, and the growing costs of meeting stiffer environmental regulations.

7. Public Administration Problems. Solid waste collection and disposal is becoming an increasingly important concern to local governments not only because of steadily increasing costs of collection and disposal, but also because of zoning problems, the need to locate facilities outside town or city limits and working with other municipalities to create regional solid waste disposal systems.

* Resource Recovery and Waste Reduction..., p.4. 
It can thus be seen that solid waste disposal is a far larger problem and one with more wide reaching implications then is commonly supposed. How we, as a society, regard our resources is reflected in how much and what kinds of waste we produce and how it is disposed of. Much can be said for long-range plans for reducing sources of waste. However, for the next few decades we may have to make the best of the residuals of a throw-away society. Various systems for the recovery of wastes have been proposed for this purpose and will be discussed in Section B. 
B. An Approach to Solving the Solid Waste Disposal Problem - Resource Recovery

The U.S. EPA's Resource Recovery and Waste Reduction Fourth Report

to Congress defines resource recovery as "... a general concept referring to any productive use of what would otherwise be a waste material requiring disposal. As such it encompasses narrower concepts such as:

" 'Recycling' - reprocessing wastes to recover an original raw material; for example, the steel content from tin cans or the fiber content of wastepaper.

" 'Material Conversion' - utilizing a waste in a different form of material, such as compost from wastepaper or road-paving material from auto tires.

" 'Energy Recovery' - capturing the heat value from organic waste, either by direct combustion or by first converting it into a intermediate fuel product. *

Resource recovery systems have the potential for mitigating the adverse effects of solid waste on the environment and on the economy while lowering the consumption of energy and material resources. Large regional facilities reduce the number of siting decisions that need to be made and their economies of scale can lower the costs of disposal to individual communities. In areas such as eastern Massachusetts (on which this paper will focus) where land is relatively scarce and expensive and where energy costs are relatively high a well thought out regional resource recovery system may be especially appropriate.

*Ibid, p.1. 
As attractive as resource recovery now seems, until recently there has been very little stimulus for the implementation of such systems. While our economy has produced an increasing amount of waste, there has been very little awareness of such waste as an environmental problem or as symptomatic of a poor system of resource management.

The historic availability of relatively cheap natural resources and energy in the United States has allowed resource recovery to be ignored. This, cambined with federal policies such as tax credits which encourage natural resource development and regulations such as rail freight rates administered by the Interstate Commerce Commission which in many cases favor virgin over secondary materials, had created a climate inimical to the development of a resource recovery industry.* D. How this Study is Organized

In the following chapters an examination will be made of the Commonwealth of Massachusetts' policy of solid waste management through a series of regional resource recovery systems. These regions are composed of municipalities which have voluntarily joined to seek acceptable long-term methods for managing their solid waste. This paper will focus on the Massachusetts approach to solid waste management as exermlified by one of these groups, the 128 West Resource Recovery Council (128 WRRC). Chapter II will follow the development of the Commonwealth's solid waste planning efforts from the inception of the Bureau of Solid Waste Disposal in 1969 to the present time-the evolution of the current system of voluntary regions. Chapter III will discuss solid waste disposal in the 128 WRRC area and regional resource recovery as an approach to solid waste management. It will also

*Ibid, page 5 . 
explore the theoretical background of regionalized solid waste management. Chapter IV will describe the 128 WRRC; its history, structure, and the processes by which sites and technologies are selected. The commonwealth's approach to solid waste management will be analyzed and the disadvantages and advantages of the approach will be discussed. Chapter V will offer an assessment of the commonwealth's policy to date and suggest future directions. 
Chapter II

SOIID WASTE POIICY AND PLANNING IN MASSACHUSETTS

This chapter will deal with the evolution of the Commonwealth of Massachusetts approach to solid waste from the inception of the Bureau of Solid Waste Disposal (BSWD) in 1969 to the present. Originally part of the Department of Public Works, now a Division of the Department of Environmental Management, the BSWD was established to coordinate solid waste planning and management and "... to assist communities in addressing the complex technical, institutional, procurement, and financial issues involved in ... [solid waste disposal]." *

A. Initial Attempts to Create a Regional Approach

1. The Raytheon Report

The first major planning effort took place when the Department of Public Works contracted with the Raytheon Service Company to produce a Solid Waste Management Study Report which was released May 15, 1972.** The report, which evaluated the status of solid waste management in Massachusetts made several recommendations which were incorporated in the state plan.

A major recommendation of the "Raytheon Report", was the development of a network of mandatory regions for handling solid waste processing and disposal throughout the state. This was based on an analysis which found "... economies attainable with a corresponding reduction in the amount of taxes needed for this service through operating solid waste management systems on a large regional scale [to be] a compelling argument for such reqionalization." ***

\footnotetext{
*State Solid Waste Plan (1977), p.l.
}

**Study of Solid Waste Disposal for Program Plan Development for the Commonwealth of Massachusetts, Raytheon Company, Burlington, MA May 15, 1972. 
Another reason given had to do with the fact that highly urbanized areas have little or no land available for the creation of solid waste disposal facilities. Regions with both urban and rural components (as proposed in the report) would have a greater number of siting options. "Those commmities possessing available land area for disposal facilities can aid their fellow, less fortunate, communities while at the same time reducing the cost impact of their own solid waste management and conforming with applicable laws and regulations,"* That is to say, regionlization was promoted as being the best approach for dealing with siting, economic, and environmental difficulties some or all of which were and are faced by all communities in the commonwealth.

\section{Mandatory Regions and Home Rule}

Although state policy still favors a regional approach, one element which eventually proved fatal to the 1972 plan was the predetermined and mandatory nature of the proposed regions. The report recommended that the Commonwealth be divided into 41 solid waste districts. The districts were to be formed by subdividing the areas served by the thirteen regional planning agencies (RPA's) in the state. The districts were to be grouped in RPA areas which, in turn, were grouped to form four "Solid Waste Supervisory Units " so that the BSWD would have a "reasonable number of agencies" to deal with. ** Proposed regions are shown in figure 1.

Using data from the "Raytheon Report", a state plan was developed by an interagency planning unit which included representatives of the Department of Public Works, Department of Public Health, Department of Natural Resources and the Department of Community Affairs. It was this group which transformed

\footnotetext{
*Ibid , page 4-1

**Ibid , page 4-11
} 
the recommendation of mandatory regionalization into state policy.*

To understand why mandatory regionalization was doomed, it is necessary to understand the political context in Massachusetts. Solid waste disposal is the responsibility of each muicipality. In order for the state to impose mandatory regionalization upon local communities a portion of their home rule powers would have to have been reduced. Legislation which was proposed to accomplish this was defeated.

At a symposium on regionalized solid waste management in June 1972, University of Massachusetts political scientist, Robert A Shanley made the following observations concerning reasons to expect such a defeat:

... (M) any cormunities in Massachusetts and in other states have representatives in the lower houses of the legislature representing their particular community, whereas there are usually no representatives of areas which dovetail with the boundaries of existing or proposed regional districts. Therefore, since many representatives in Massachusetts are considered to be, or consider themselves to be delegates from a particular commuity and preservers of the life style of that community, an additional political burden is placed on those who see the need for regional plans to improve the life and environment of the metropolis. And even in those areas where a legislator represents a number of communities, in Western Massachusetts, for example, there may not be the necessary pressure or

*Commonwealth of Massachusetts. Solid Waste Management Plan, Summary Report. undated, c. 1972. Introductory Letter 
crying need for regionalization of solid waste facilities.*

In 1973, House Bill \#6643 was submitted. Section 19 of this bill amended the authority of the Bureau of Solid Waste Disposal to allow it to: ... (D) esignate solid waste disposal districts and solid waste disposal regions ....Solid waste disposal districts shall, wherever practicable, consist of a single city or town, or a part thereof, or two or more contiguous cities and towns, or cities and towns, or parts thereof. ...Any city or town who, after a public hearing held jointly by the Department [of Public Works] and the Department of Public Health, is found to be unwilling or unable to operate its solid waste disposal facility in compliance with existing state laws, rules and regulations, including without limitation the laws, rules and regulations relating to operation of solid waste disposal facilities, air pollution, water pollution, wetland protection and protection of waters of the Commonwealth shall be required to participate in the state program of solid waste disposal. **

House Bill \#6643, was defeated, as had been predicted. This left state policy makers the task of designing a regional approach that did not interfere with home rule.

*Robert A. Shanley, "Local Political Systems in Relation to Regionalization" in Proceedings of Regionalized Solid Waste Management, Technical Guidance Center for Environmental Quality, Cooperative Extension Service, University of Massachusetts at Amherst, 1972. pp 74-75

**Commonwealth of Massachusetts, House Representatives, \#6643, May 14, 1973 
B. Voluntary Regionalization

\section{Legislation}

The legislation which was finally passed in 1973 removed the mandatory nature of $\mathrm{H} \# 6643$, while allowing for voluntary groupings of municipalities for the purpose of solid waste disposal:

A solid waste disposal district shall wherever practicable consist of a single town, or a part thereof, or two or more contigous cities or towns, or cities and towns, or parts thereof, provided that no city or town, or part thereof shall be included in more than one said district. Fach district shall have an advisory committee comprised of one member from each city or town in such district, who shall be appointed by the city manager in a city having a city manager, by the mayor in any other city, by the selectmen in a town having selectmen, and by the town council in any other town ... Unless otherwise approved by the governor, unburned solid waste shall not be disposed of in a landfill established under (these) provisions ...unless such unburned solid waste was generated within the district where such a landfill is located, provided, however, that solid waste or by-products thereof, may be freely transported throughout the Cormonwealth for the purposes of recycling, reclamation and resource recovery.*

It was this provision which set the legal basis for the present system of regional resource recovery in Massachusetts. Although the size, shape and 
membership of regional groupings was not specified, municipalities were allowed to join together to seek solutions to their common solid waste disposal problems.

2. The Massachusetts Solid Waste Management Plan of 1975

By the time the November 1975, Massachusetts Solid Waste Management Plan was promulagated a state policy featuring a system of voluntary regional resource recovery systems had evolved. The overall goal of the Commonwealth was "... to maximize recovery of resources from all solid wastes inraneconomical and envirommentally sound manner."* The role of the state became that of catalyst in assisting regional groups of municipalities to form for the purpose of solving their solid waste disposal problems.**

The overall state system was conceived as a loose and suggestive one, rather that the rigid and mandatory system suggested in the Raytheon Study:

The need, number, size, and location of resounce recovery facilities is a function of the volume and geographic concentration of solid waste. Based on current volumes and locations of solid waste, it is estimated that a statewide network of regional systems can support a mix of three large (3000 ton/day each) resource recovery plants and four smaller (1500 ton/day each) plants. Actual sizing and location of regional facilities can only be accomplished after a detailed analysis of the waste generation and location, markets, and transportation systems..."***

*Commonwealth of Massachusetts. Solid Waste Management Plan, November, 1975 unpaginated

**Ibid

$\star \star \star \star I b i d ~$ 
The plan goes on to suggest general locations of plants, incorporating existing resource recovery facilities in Saugus and East Bridgewater, which are shown in figure 2.

The 1975 plan deliniates roles for the state, commuities, and the private sector. The private sector was to be utilized for system construction and operation under public control. Public functions would include: organization, implementation, administration, and regulation of the system. Within the public sector each municipality was to retain its primary responsiblity for the disposal of solid waste. The state's role was to include responsibility for overall organization and administration of the regional systems. **

C. Current Regional Solid Waste Policy

1. The 1977 Plan Update

The latest update of the State Solid Waste Plan was completed in September, 1977. It retains, intact, the regional resource recovery approach outlined in the 1975 plan. *ᄎ*

Although the present system of regionalization is not mandatory the state retains some leverage over the municipalities. The Division of Air and Hazardous Materials (DAHM) of the Department of Environmental Quality Engineering (DEQE), under the provisions of Section 150A of Chapter 111 of the General Laws of Massachusetts," ... continuously oversees and routinely inspects existing solid waste disposal facilities,

\footnotetext{
*Ibid

**Ibid

***Conmonwealth of Massachusetts, 1977 op. cit.
} 


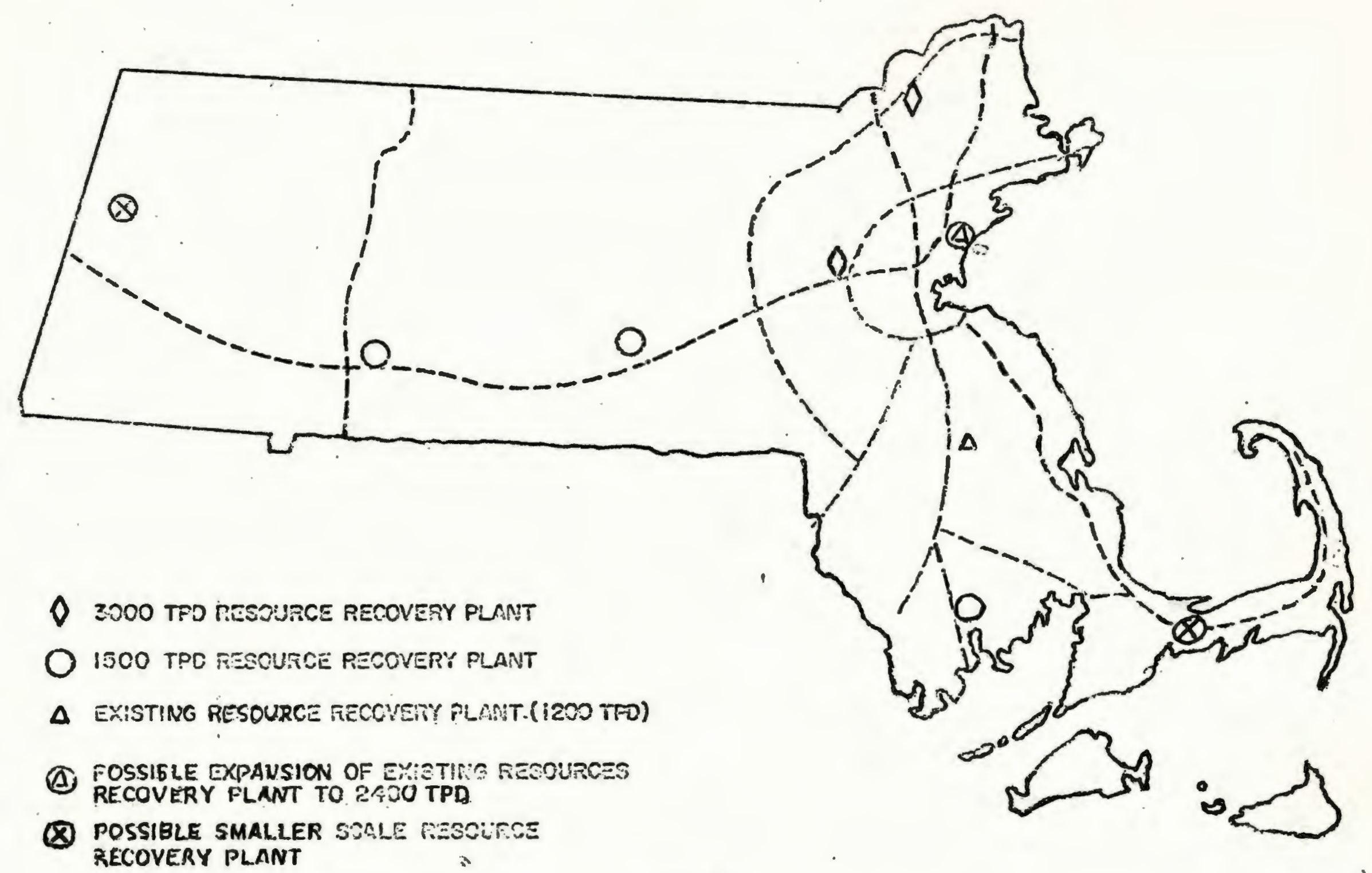

Figure 2

PROPOSED RESOURCE RECOVERY PLANT LOCATIONS IN COMMONWEALTH OF MASSACHUSET IS

Source: Commonwealth of massachusetts

Solid Waste Management Plan, November 1975 
examines proposed sites and expansion of existing sites for the disposal of solid waste, .... and determines whether the assignment of such facilities should be modified or rescinded."* If the DAHM finds that a municipal facility is not being operated in compliance with its regulations it can have the Office of the Attorney General issue orders to force compliance. Cities and towns so ordered, or under threat of such orders are in need of economically feasible alternatives.

State policy has evolved from the beginnings of official recognition in the late 1960 's that the state has a role in solid waste management (as distinquished from regulation) to the present system of state assisted voluntary regionlization. The present policy emerged after the attempt to impose mandatory regions proved to be politically infeasible. While it will be seen in this paper that there are problems with the current approach, these are also a number of advantages.

2. Towards Implementation - The 128 West Resource Recovery Council The 128 West Resource Recovery Council (128 WRRC) is one of several regional groups of municipalities in Massachusetts organized to provide a solid waste disposal alternative for its members. Some member commities may be under orders from the Attorney General, to comply with state regulations, such orders may be threatened or pending, some communities may be running out of space in their landfill, their disposal costs may be increasing, they may suffer from a combination of these problems, they may simply wish to maximize their future options, or there may be a combination of such factors. The state system of voluntary regional resource recovery groups such as 128 WRRC was devised to offer a viable alternative for

\section{*Ibid}


these communities. Subsequent chapters of this paper will discuss the manner in which the solid waste disposal needs of commuities in Massachusetts are addressed through groups such as the 128 WRRC. 
Chapter III

Regional Resource Recovery

A Background and Discussion

In this Chapter an attempt will be made to examine some of the factors which have influenced the commonwealth's approach to regional solid waste disposal. The 128 West Resource Recovery Council (128 WRRC) has been selected as an example of a state sponsored resource recovery project for several reasons: It is more recent than the first statesponsored regional project, the Northeastern Solid Waste Project, and thus has benefitted from the lessons learned from this experience; of the remaining projects (others are in regions surrounding Springfield and Worcester) the 128 WRRC has progressed the furthest toward implementation; and the nature of the region is interesting in its heterogeneity, encompassing urban, suburban, and rural communities. The chapter will first discuss the present means of land disposal of solid wastes used by most 128 WRRC member communities. There will then be a discussion of alternatives to land disposal, specifically resource recovery. Finally this chapter will take up the issue of regional approaches to resource recovery.

\section{A. Current Solid Waste Disposal Practices and Their costs}

The 128 WRRC is a group of communities in the Boston Metropolitan Area which have joined together in seeking a regional solution to their mutual solid waste disposal problems. The commuities involved vary greatly in size and character. The region includes an:large city, Boston (population 600,000); smaller urban centers such as Cambridge $(102,000)$, Newton $(86,657)$, and Waltham $(60,000)$; 
128 WEST RESOURCE RECOVERY COUNCIL

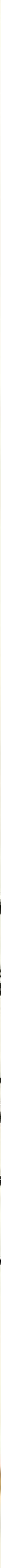


suburban communities such as Natick $(33,000)$, Wellesley $(27,000)$, and Weston $(14,000)$; and rural communities such as Stow $(5,000)$, Sherborn $(4,310)$, and Boxborough $(2,756)$.

At present, virtually all of the 128 WRRC communities dispose of their solid wastes in landfills, some community owned and operated, others run by the private sector. What many of the land disposal facilities have in common is that they are run in violation of Massachusetts landfill regulations. *

Another problem affecting communities of the region is that even in those landfills which are run in an environmentally sound manner, capacity is finite. In ten, five, or fewer years communities with their own landfills will either have to find a new environmentally acceptable site, or contract to have their waste disposed of outside of their borders. The first alternative is often physically impossible in the more developed parts of the region, and politically or economically not feasible even where land exists. Thus, in virtually all of the 128 WRRC municipalities, land disposal of solid waste is now, or can expected to be in the near future, a serious fiscal, environmental, and political problem.

The costs of land disposal vary greatly in the 128 WRRC region. For example, the Town of Sherborn pays about $\$ 23.63$ per ton as compared to the Town of Meafield whichnays about $\$ 4.45$ per ton.**

There can be a number of reasons for such disparities. In some cases towns report lower costs because they fail to account for all cost factors. Techniques of collection and disposal differ from locality to locality.

\footnotetext{
*Commonwealth of Massachusetts (Bureau of Solid Waste Disposal) and the MITRE Corporation, 128 West Resource Recovery Council Status Report January, 1978. (Appendix IV). **Ibid , p.48-49
} 
Often, however, lower disposal costs are a function of environmentally unsound disposal practices.

An increasing amount of pressure from the DEQE is being brought to bear as federal funding enables that agency to increase its level of enforcement efforts. Specifically, the Resource Conservation and Recovery Act of 1976 (RCRA) ** mandates each state to conduct an "open dump inventory". This process calls for each land disposal facility to be examined against criteria to be promulgated by the EPA. In Massachusetts DEQE's Division of Air and Hazardous Materials (DAHM) will have the responsibility for carrying out the open dump inventory. It is expected that this comprehensive inspection will force many municipalities in the commonwealth to abandon inexpensive but envirommentally unsound methods of waste disposal thus increasing the demand for acceptable alternatives.

*Ibid, (appendix IV).

**Public Law 94-580 


\section{B. An Alternative to Land Disposal}

From the prospective of municipalities (which, it should be remembered, have responsibility for solid waste disposal in Massachusetts) an acceptable alternative would be one which would simultaneously satisfy state and federal regulations and have a relatively attractive price tag. While the DEQE has been exerting steadily increasing enforcement pressures on municipalities, another branch of state government, the Bureau of Solid Waste Disposal, has been engaged in providing an overall conceptual framework and specific technical assistance to municipalities for development alternatives (see Chapter II).

\section{Resource Recovery}

There are a number of factors which make resource recovery a particularly attractive approach to solid waste disposal in Massachusetts: It is not land intensive as are the traditional dumps and landfills; large regional facilities require fewer politically difficult and, at times,environmentally dubious siting decisions; the types of systems being seriously considered produce, as their major output, energy, an especially valuable comodity in New England with its high dependence on expensive imported oil; and there is the promise that resource recovery can keep disposal costs to communities stable over a relatively long period.

It may be useful at this point to describe some of the major types of technologies which will be considered by the 128 WRRC*:

\footnotetext{
*This discussion is based, in part, on material from: Steven J. Levey, and Gregor H. Rigo Resource Recovery Plant Implementation: Guides for Municipal Officials: Technologies, (SW-157.2)) Washington D. C., Environmental Protection Agency 1976.; and the 128 West Resource Recovery Council Status Report (Section I)
} 
- Waterwall Incineration. In this process steam is generated by burning the bulk wastes as delivered to the facility. Steam is created from water which is circulated through the area of combustion in a number of tubes. Steam can then be sold directly to a nearby manufacturer or it can be converted to electricity which, in turn, typically can be sold to markets such as electric utilities. The sale of steam is potentially more lucrative since it involves less energy loss and there is no need to insert in generating equipment. However, the direct sale of steam necessitates the market be very close. Thus as a practical matter, it is often necessary to sell electricity at a lower return per unit of waste incinerated. Waterwall incineration is the best proven of the energy recovery technologies. Such systems have been successfully operated in Europe for more than twenty years, and more recently in the United States at sites such as the one in Saugus, Massachusetts. The reliability of waterwall incineration makes it a relatively attractive choice for municipalities. It does have disadvantages, however, such as the need for nearby markets (even electricity markets should be relatively close to prevent excessive transmission loss) high capital cost, and the relatively low value of materials typically recovered by this process (i.e. the post - incineration recovery of ferrous metals). 
- Refuse Derived Fuel (RFD). Refuse derived fuel or $\mathrm{RDF}$ is a less proven but potentially more flexible technology than waterwall incineration. RDF is made from the combustible portion of solid waste after it has undergone a separation process. The combustible fraction is pulverized and made into either a confetti-like, powdery, or fiberous fuel which can then be marketed to utilities or industries as a supplement to coal or oil in existing boilers. While this system is potentially less capital intensive that waterwall incineration, and the location of the plant is less of a limiting factor, RDF is not a fully demonstrated technology, hence, it presents a greater risk.

- Pyrolysis. Pyrolysis is a process in which the combustible fraction of the refuse is subjected to heat in the absence of oxygen to convert it to a low BTU gas, or an oillike liquid. This process has many of the same advantages as RDF but is the least technically reliable process, at this time, of the three discussed here. 
Each of the energy recovery technologies is compatible with material recovery and it is assumed that the system chosen by the 128 WRRC will include this component. The most readily marketable materials include ferrous metals, glass and aluminum.

\section{Impacts of Resource Recovery Systems}

Resource recovery can be expected to create a number of positive and negative direct and indirect impacts which are discussed in the 128 West Resource Recovery Council Status Report. These include:

- Payments Lieu of Taxes

This is a direct benefit, mandated by state law, which requires a payment of one dollar per ton of refuse to the community in which the facility is sited. In a system which takes in 2000 tons of refuse per day (if one assumes 310 days of operation per year) $\$ 620,000$ per year would go to the host community.

- Regional Economies of Scale Versus Transportation Costs

Because the system will be a regional one, costs to individual communities will be reduced as more communities participate. There is, however, a limiting factor to this benefit - the increase of transportation costs as the size of the region increases.

Studies by the MITRE Corporation (an independent, non-profit consulting firm retained by the Bureau of Solid Waste Disposal to render technical assistance for projects such as 128 WRRC) have shown "...that transport of solid waste over distances of 40 miles or more can be 
'economically feasible,' when considering these three key questions relating to economic feasibility:

(1) The benefits of economies of scale in processing achieved by having a larger quantity of solid waste available for processing.

(2) The alternative cost for solid waste disposal

by whatever other option is available locally, considering also projections about increases in this cost.

(3) The manner in which overall regional costs of solid waste transport, processing and disposal is to be apportioned. *

In the case of the 128 WRRC, it is assumed that the transportation costs will not increase with plant size as quickly as processing costs decrease. Therefore, the total costs of processing and transportation is expected to decrease as plant size increases.**

- Iocal Employment

The construction of a resource recovery plant is expected to generate about 600 to 700 man-years of employment over a two to three year period. Depending upon the type of process selected and the size of the facility from 50 to 100 permanant jobs should result from resource recovery system operations. ***

* Steven G. Lewis, "Regionalism: Its Role in Resource Recovery"in Proceedings of the Fifth National Congress in Waste Management Technology and Resource and Energy Recovery, Washington, D.C. U.S. Environmental Protection Agency, 1977. P. 174

**128 West Resource Recovery Council Status Report p. 30

$\star * *$ Ibid p. 30 
- Indirect Benefits

The 128 WRRC expects that a multiplier affect may result from some of the income produced by the facility being spent in the host community in turn, attract additional commerce and employment to the locality.*

- Increased Traffic

A large resource recovery facility, with a capacity of 1000 tons per day or more, can be expected to generate a large amount of traffic from trucks making refuse deliveries. A 1700 ton per day facility, for example can be expected to produce a traffic level of 300 vehicles per day.

There are several steps which can be taken to minimize adverse effects (congestion, noise, and pollution from exhaust fumes) caused by such a traffic volume. These include proper scheduling of deliveries, proper design of access roads and refuse receiving areas, the location of transfer facilities to enable the consolidation of loads of refuse into fewer trucks, and the location of facilities near major highways to minimize traffic through host comminity roads, or those of other nearby communities. **

- Environmental Impacts

There are a number of possible environmental impacts which may result from the implementation of a resource recovery system. While the degree of impacts will vary with the specific technology used, in general such a system will have potential impacts relating to air quality noise, odor, water effluents, and the disposal of residue. While

* Ibid, p. 30

** Ibid, p. 30-31 
these possible negative side effects should not be lightly regarded, there is reason to believe that they can be kept within acceptable limits. When done properly, it is reasonable to assume that a resource recovery system will be environmentally far superior to traditional land disposal methods. *

C. Regional Approaches to Solid Waste Management

1. The Need for Regional Organization

In the late 1960's and early 1970's awareness of the nature and magnitude of the solid waste problem grew. Alternative methods were proposed to more satisfactorily deal with waste. However, as was mentioned earlier is this paper, the new approaches proposed are complex and capital intensive. Even new, environmentally sound, landfill techniques such as special preparation of landfill areas and various types of pre-disposal treatment of the wastes, were found to be far costlier than conventional methods.

Jane Gilbert has found that:

As technology improves and the need for more efficient systems of disposal rises, it is likely that even more expensive facilities will be required. (The current, popularity of transfer stations and recycling plants are evidence of this trend.) Thus, the small municipality is likely to

\footnotetext{
*The environmental aspects of a large scale waterwall incineration resource recovery system is discussed at length in the Draft Environmental Impact Report on the Northeastern Massachusetts Resource Recovery Project prepared by the Massachusetts Bureau of Solid Waste Disposal with the assistance of the MITRE Corporation in June, 1978.
} 
find it increasingly ...difficult to undertake effective action alone in the future.*

2. Theoretical and Practical Constraints on Regional Organization

In a forward to an article published by EPA in 1971**, Richiard D. Vaughan, then Acting Comissioner of EPA's Solid Waste Management Office, pointed out a major obstacle, lack of organization definition: ... (T) here has been considerable discussion about whatorganizational.forma solid waste management system should take. It is obvious from even a cursory study that most solid waste management systems have been operated haphazardly and scarcely deserve to be called "systems" because responsibilities are so fragmented. The lack of a proper organizational framework having adequate power at an overall jurisdictional level adds to the problem. It is clear, therefore, that one of the most important ways to solve solid waste problems is to define and structure an effective and efficient system and to set it within an appropriate overall organizational framework.

Gilbert found that a common theme of several studies she examined was that due to their political fragmentation, metropolitan areas were

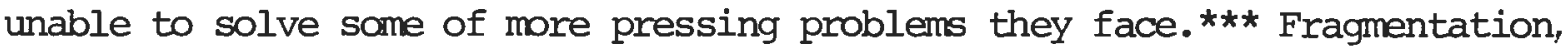
according to Gilbert, leads to inefficiencies for several reasons:

*Jane Gillbert, Efforts at Intermunicipal Cooperation for Solid Waste. RSRI Discussion Paper Series: No. 68, Philadelphia, Regional Science Institute, October, 1973, page 9.

**Richard 0. Toftner, and Robert M. Clark, Intergovernmental T.pproaches to Sölid Waste Management Forward by Richard D. Vaughan, Report \#SW-47ts, Washington D.C.: :U.S. EPA, 1971.

$\star \star \star$ Efforts at Intermunicipal Coordination for Solia Waste p. 1. 
- Providing for small communities, services for which there are economies of scale, results in high unit costs. Thus, fragmentation can lead to relatively high costs for such services.

- Decisions made (or not made) by one unit of government often produce externalities.

- Where there are externalities, affected groups should have a voice in the decisions made. When there are two or more separate governments in an area this does not occur. "(C)hoices in metropolitan areas tend to be responsive only to a subset of all persons affected by a problem."*

The notion of a single metropolitan government as an alternative to fragmentation is also found by Gilbert to have difficulities since both externalities and economies of scale vary from one service to another. A single metropolitan government could lead to inefficiencies from the provision of services either on too large or too small a scale. With regard to externalities, a decision making unit should include all those affected by a decision, but no others, since unaffected persons could easily make capricious choices. In addition, a single metropolitan government could tend to minimize freedom of choice by the imposition of a single standard. **

Gilbert concludes that, in many cases, the best level of organization may be somewhere between a single municipality and an entire metropolitan

\footnotetext{
*Ibid , p.3

**Ibid , p. 5
} 
region in size. Often, it may be optimal for a number of municipalities to coordinate their activities and to provide them jointly.* The manner in which the 128 WRRC was formed as such a sub-metropolitan region will be discussed later in this paper.

Toftner and Clark state that the magnitude of an ideal solid waste region, and what defines it is not clear. "... (W) hatever the criteria used -- geographic, demographic, hydrological, economic, or community of interest -- regions will include several contigious political entities and will inevitably present an intergovernmental problem if functional unification is attempted." They argue from this that the problem is "... more one of intergovernmental coordination than regionalism."**

As the Massachusetts experience has shown, the attempt to impose regions on the municipalities of the state was viewed as by them an arbitrary abridgement of local perogative (see Chapter II). Clearly, whatever theoretical merits those mandatory regions processed, without local assent they were of little value. Hence, given the political context of assachusetts, Toftner and Clark's emphasis on intergovernmental coordination makes a good deal of sense.

3. The Advantages and Disadvantages of Delocalized Approaches to Solid Waste Management

As has been suggested by the foregoing discussion, there has been a great deal of discussion and some attempts at implementation of approaches to solid waste disposal involving more than one community. For the sake of inclusiveness such approaches will be referred to as delocalized

\footnotetext{
*Ibid , p. 7

**Intergovernmental Approaches... p.l
} 
rather than regional or intergovernmental.

One type of delocalized approach which is frequently discussed is an authority with the mission of providing services to municipalities. According to Hudson "...(s) uch an authority would be able to achieve economies of scale in its operation to reduce the total cost to society, and would also have more chance of success in using desirable sites since local opposition would be less effective."* with regard to the last point, Hudson elaborates that many communities have major difficulties lacating solid waste facilities aven through those facilities are beneficial to residents of the community in general. Hudson also points out significant advantages such an authority would bring about through regionalization, especially that of lowering costs.**

Gross has summarized the advantages of a delocalized approach as follows:

\section{Economic}

Economies of scale in processing and disposal facilities might lead to lower capital and operating costs for overall system.

Larger base of support for financing high capital investments for modern facilities. Environmental

Special equipment for protecting the environment becomes economically feasible for larger facilities. Larger land base for selection of suitable

\footnotetext{
*James F. Hudson,"The Need for Continued Local Control Over Solid Waste Management", unpublished paper, Massachusetts Institute of Technology, 1973 p. 5

**Ibid , p.6
} 
sites for facilities.

Reduces the "critical" nature of the solid

waste management problem and thereby eliminates

rationale for haphazard solutions.

Political

Reduce the dependence upon private industry

for solutions.

Relieve local officials of a sensitive political

issue.

Social

Eliminate the absolute need for "organized crime" in solid waste management. *

Although the advantages of a delocalized approach are obvious, there have been disadvantages observed in a delocalized authority. Hudson defines a delocalized authority as "a mission - oriented body with a responsibility of providing solid waste processing and disposal service to users in the state..."** Such an authority would also be understood to have power of eminent domain and, as such, be free from the control of local zoning. $* \star *$

Among the disadvantages of a delocalized authority cited by Hudson is the potential for disruption of local land use plans. Another problem, he points out, is the possibility of preemption where it becomes impossible for a.municipality to regulate solid waste within in its borders.even if state regulation is not enforced. A third issue listed by

*Frederick P. Gross, Issues in the Regionalization of solid Waste Management Planning. Report R75-26, Cambridge, MA: Department of Civil Engineering, Civil Engineering Systems Laboratory, Massachusetts Institute of Technology, 1975., p.151

**!!The Need for Continued Local Control ..." p.12 
Hudson deals with implementation. The very existence or even likelihood state authority could remove whatever incentive a local government might have for solving its own problems.*

Hudson finds perogatives such as zoning especially vulnerable to mission - oriented agencies "... who give scant considerations to some of the impacts of their actions"** He makes an analogy with other mission-oriented agencies such as those used to develop the Interstate Highway System. At first, roads were designed and constructed under this program based upon a relatively narrow definition of mission. Later, although implementing agencies retained their legal authority, political opposition has blocked most of their efforts. Thus we seem to have two cases: either the mission gets accomplished to the exclusion of other objectives; or, even with legal authority available, the mission does not get accomplished because of political opposition from impacted groups, no matter how necessary the road to the general population. ***

Whatever the advantages of a mission-oriented solid waste authority at a level beyond the local, there is reason to expect that such agencies often bear the seeds of their own undoing. In fact, as can be seen from the Massachusetts attermpt to impose regions (Chapter II), political opposition can prevent such agencies from ever starting.

\footnotetext{
*Ibid , p.12-13

**Ibid , p. 14

***Ibid , p. 14
} 
Gross has found an even wider array of disadvantages to a regional approach, which include, but go beyond those disadvantages described in Hudson's discussion of regional authorities:

\section{Economic}

Costs associated with implementation may be

high if objections exist to proposed regionalization.

Higher transport costs.

Possible need for transfer stations.

Environmental

Impacts of solid waste disposal can become concentrated in one area especially those from increased trucking and leachate in the case of landfills.

Large powerful agencies are difficult to regulate and they often loose sight of multiple objectives.* Political

[The overriding] ... of local land use controls may result [in the] ... inability to react to ... sensitive [environmental] issue: [s].

Antagonism between some local governments and state or regional authorities may become very aggravated.

Social

Less imput from people [the public] in planning solid waste management as well as other important land-use decisions.**

*This calls to mind the Tennessee Valley Authority which, although it is an agency of the same Federal Govermment as the Environmental Protection Agency, is a notorious polluter.

**Issues in the Regionalization of Solid Waste Management Planning, p.152 
4. Requirements for a Sound Approach to Regional Resource Recovery

It is possible to extract several of the points discussed in this chapter to make a list of questions with which a resource recovery project might be evaluated:

1. Does the approach provide "...a proper organizational framework having adequate power at an overall jurisdictional level..." (Vaughan in Toftner and Clark).

2. Does the approach work at an appropriate level between local fragmentation and a single metropolitan entity? (Gilbert)

3. Does the approach avoid the dangers "of single mission authorities? (Hudson)

4. Does the approach provide the advantages listed by Gross and how well does it deal with Gross': list of disadvantages?

In Chapter IV, the 128 WRRC will be described in more detail. Its organization, structure, and its movement toward implementation will be discussed, and it will be evaluated in terms of the questions posed in this chapter. 


\section{Chapter IV \\ The 128 West Resource Recovery Council \\ An Exarnple of the Massachusetts Approach to Regional Solid Waste Disposal}

A. The Organization and Progress of 128 WRRC

The 128 West Resource Recovery Council (128 WRRC) was formed by civic leaders and interested citizens in the West Suburban Boston Area in the spring and summer of 1975. Responding to the increasing costs of existing solid waste disposal practices, 23 communities of the 34 initially contacted joined the 128 WRRC. This initial organization took place with the assistance of the Bureau of Solid Waste Disposal (BSWD) *

The 128 WRRC embodies the Commonwealth's approach to regional resource recovery which is described in. Chapter II. It is voluntary in nature, both in the sense that municipalities may or may not choose to affliliate themselves with the council, and in the sense that the community representatives who make up the 128 WRRC are often private citizens, volunteering their time. (Some municipal officials participate directly in council activities as well).

1. Events Ieading to Implementation

The principal accomplishments of the 128 WRRC during the first two and half years of its existence were the formulation of its structure and bylaws and the development of a planning approach to implement a resource recovery system. This approach was an adaptation of that

\footnotetext{
*128 WRRC Status Report, p. 16
} 
presented in the 1975 State Plan (see Chapter II).

The 128 West Status Report (p. 35) set forth several basic conditions to be met before a resource recovery system could be implemented. Given the decision on the part of the 128 WRRC to open the design, construction, and operation of such a system to competitive proposals by private industry it was determined that there must be:

- A perceived solid waste disposal problem which must be solved.

- A potential market (or markets) for resource recovery products.

- An available comitted supply of municipal refuse tonnage requiring processing and disposal.

- One or more resource recovery sites...

- A viable approach for project financing.

As related in Chapter III, there is most definitely a perceived solid waste disposal problem throughout the region. It can be expected that this perception will become increasingly vivid as conventional options grow more expensive and difficult.

Given the perception and, indeed, the reality of the solid waste disposal problem in the 128 WRRC region, there is a potential for sufficient tonnage to support a facility of 2000 to 3000 tons per day or more capacity.*

*Ibid, Table III -1 and III - 6 
The commitment of this tonnage will take place after a contractor has been selected. This can be expected to be one of the most difficult stages of the project since communities will be expected to make longterm (20 Year) commitments of their solid wastes.

A study was conducted on behalf of the 128 WRRC by the BSWD and its consultant, the MTTRE Corporation, to determine potential markets. The conclusion of this study was that the sale of electricity to utilities is the most practical energy sales option. While markets for recovered materials were also examined, it was determined that these were not as crucial to economic success as energy markets.*

It is expected that the financing of a resource recovery system will be accomplished through tax-exempt revenue bonds issued by the host community's Industrial Development Finance Authority. The advantage of this approach is that it does not require the full faith and credit of the host community but rather depends on revenues produced by the system. The financial liability of each community, including the host community, is limited only to their commitment to supply a minimm amount of refuse tonnage over a period of twenty years. The details of a financing arrangement will be part of a contractual arrangement reached between each community and whichever firm is selected as contractor. **

\footnotetext{
*Ibid p. 31

**Ibiá p. 31
} 


\section{Site Selection}

The selection of a site not unexpectedly, turned out to be a long and involved process. It began formally, when in November, 1975 the Technical Committee of the 128 WRRC invited each participating commuity to submit site nominations. The final deadline for nominations was in April 1977, at which time the 128 WRRC selected four sites for further analysis by the Bureau of Solid Waste Disposal.*

It is interesting to note that the site nomination process took nearly one and a half years. Martha Stone, a former Vice Chairman of the 128 WRRC, is of the opinion that the rate of progress of the 128 WRRC has been directly proportional to the degree of assistance rendered by the Bureau of Solid Waste Disposal.** The BSWD's staffing was such that relatively little time was devoted to the 128 WRRC until November, 1977 when the staff of that agency was expanded. The progress since that time has been much more rapid.

The four sites selected for further analysis were in Bedford, Sharon, Stoughton, and Weston. These sites had each met the preliminary criteria of accessibility and availability. In the BSWD's more detailed analysis, each site was reviewed from the perspective of environmental impacts (e.g., air quality, water quality, noise impacts), economic impacts (e.g., potential for the development of steam markets, adherence to the Commonwealth's economic development process) and other

\footnotetext{
*Ibid p.67

**Interview . July 1978
} 
criteria such as zoning, whether there existed a nearby backup landfill, access, and perhaps the most important of all criteria, political feasibility.

Each site was rated from zero to four for each of the criteria based upon the following system:

0 - site unacceptable for that criteria (sic)

1 - site acceptable but only under limited conditions or modifications related to that criteria (sic)

2 - site acceptable but poor choice based on that criteria (sic)

3 - adequate based on that criteria (sic)

4 - good choice based on that criteria (sic)*

The site analysis showed all of the sites to be roughly comparable, with one exception. Stoughton had the only site which met the test of political feasiblity. Sharon was rated "?" at the time because the town meeting which eventually rejected the use of the site for resource recovery had not been held. Weston was rated "I" because their Board of Selectmen said they wanted to wait until a detailed proposal was presented. This was satisfactory because the competetive proposal process is an open one and the 128 WRRC had determined that a site should be selected prior to a specific proposal. Bedford was rated "l"

*Ibid p. 89 
because there appeared to be no expression of citizen support. only Stoughton, with a rating of "3", was found to be politically feasible.*

3. Political Difficulties in Siting Resource Recovery Facilities

The Commonwealth has become especially sensitive to the issue of political feasiblity because of the difficulties encountered in the Northeastern Resource Recovery Project. In that case the City of Haverhill had originally agreed to be the host community for the proposed resource recovery facility. Local political opposition developed, ostensibly on the grounds that such a facility would be environmentally hazardous. The City Council, in response to this opposition, voted to rescind Haverhill's host status.

There was a wide-spread belief among members of the Northeastern Solid Waste Committee (NFSWC, then the Greater Lawrence Solid Waste Commitee, GISWC) that the Haverhill City Council's vote had political overtones going beyond the merits of the project. John Albis, then the Chairman of the GISWC, was quoted as saying, "The issue is a political football in Haverhill because of the upcoming election."** Alden Cousins, who was at that time the Director of the BSWD, also felt that the issue had become highly politicized. It had not only becóme the "political football" that Mr. Albis had referred to but that there was the possibility that some of the opposition was inspired by backers of competing projects.***

\footnotetext{
*Ibid. p.90

**Lawrence Susskind and Richard Newcome. The Obstacles to Regional Resource Recovery: A Massachusetts Case Study. Environmental Impact Assessment Project, Laboratory of Architecture and Planning, Massachusetts Institute of Technology, December, 1977.

***Interview, September, 1978.
} 
After the initial rejection by the City Council, elections were held and the new Mayor and Council agreed to reconsider Haverhill's status. A public hearing was held on this matter, following which the new City Council agreed to resume host status. Political opposition once again was mounted in the form of a referendum in which voters overwhelmingly opposed the project. This caused the City council to again rescind Haverhill's host status. Eventually, the site was shifted to a politically more hospitable community, North Andover.

Much of the difficulty in Haverhill can be traced to the unusual political situation there. This, at least, is the view of the BSWD.* Suskind and Newcome feel that the difficulty was, in large part, inherent in the Commonwealth's approach. These authors claim that their case study suggest "...host officials are likely to have difficulty coping with the technical issues (intertwined with the political judgements) that have to be made in siting a resource recovery facility. "**

William P. Gaughan, Director of the BSWD, in a letter to Professor Susskind, disagreed with that conclusion. Gaughan criticized the study for drawing general conclusions on a single case. He found the above quoted comment "...unfair to the multitude of municipal officials outside of the City of Haverhill who were not consulted for this case study."***

\footnotetext{
*The Obstacles to Regional Resource Recovery... footnote, p. 52. **Ibid P.52. ***William P. Gaughan, Letter to Professor Larry Susskind, December, 1977.
} 
There are a number of complex technical issues which need to be faced by local officials. The siting of a resource recovery facility may be one of the more complex. It is the view of the BSWD that their role is to assist communities make these technically complex decisions in a disinterested manner. It is felt that with this type of preparation local officials will be more able to cope with the political problems which will inevitably arise.*

In the case of Stoughton, the site which emerged from the 128 WRRC selection process, local officials are reasonably confident that there is sufficient political support for the town's host status. In its recommendations to the full Council the 128 WRRC Technical Sub-comittee stated: Stoughton should be selected as the preferred site for the construction of a large regional resource recovery facility. Each of the four nominated sites has problems that need to be dealt with, including Stoughton. The factor that causes the Technical Sub-committee to unanimously recommend this site is it has received public approval more than once. A vote of Stoughton's Town Meeting rezoned the parcel of land east of Route 24 [for a resource recovery facility] . Another vote of [the] town meeting granted the Industrial Development Financing Authority special

\footnotetext{
*Ibid.
} 
power to approve financing for a resource recovery facility. The political feasibility for use of this land appears to be well established.*

\section{The Request for Proposals}

After the site selection process was completed the BSWD and the MITRE Corporation prepared a Status Report (which has been extensively cited in this paper) for the 128 WRRC. This report served two major purposes. The first, as a tangible product which embodied the 128 WRRC's past accomplishments and outlined its approach to implementation. The second purpose it served was as a base for future activities both as a reference and a strategy document.

The completion of the Status Report in January, 1978 led to the next step in the implementation process, the development of a request for proposals (RFP). The 128 WRRC Technical Cormittee with the assistance of the BSWD and the MITRE Corporation, worked on this document from February 1978 to its issuance in August 1978. The following objectives were pursued to establish the goal of regional resource recovery system:

- Creation of an environmentally sound waste disposal alternative.

- Maximization of recovery of energy and

*128 WRRC Status Report, p.119. 
materials from municipal solid waste.

- Minimization of financial risk

to participating communities.

- Maximization of system reliability

- Regional economies of scale to

achieve the lowest possible disposal

costs.

- Minimal reliance on landfill.*

A bidder's conference was held in August 1978 at which time the RFP was distributed to potential bidders. At the time this is being written there are several major resource recovery firms working on proposals which are due on March 16, 1979. When proposals are received they will undergo a two stage evaluation by the 128 WRRC Technical Committee, with the assistance of the BSWD and other agencies of the Cormonwealth, and the MITRE Corporation. Proposals are to be rated not solely on the basis of cost, but rather on several criteria. The first stage of the evaluation will consist of a screening of all proposals for:

- Adequate Technical Plan

- Adequate Marketing Plan

- Adequate Management Capability

- Acceptable Schedule

- Acceptable Financial Plan

\footnotetext{
*The 128 WRRC Technical Committee, Commonwealth of Massachusetts, and the MITRE Corporation. "Project Description" (Summary of RFP) July, 1978 p.1.
} 
- Adequate Environmental Quality

- Acceptable Level of Exceptions to

Proposed Contract. *

Those proposals which successfully pass the initial screening will be further evaluated on the basis of more detailed, weighted criteria. Each criterion will be on one of three levels: prime importance, moderate importance, or lower importance. The following is a summary of some of these weighted criteria:

Examples of process design proposal criteria are: soundness of plan for integration of equipment and processes (prime importance), capacity expansion capability (moderate importance), and operating and maintenance plan (lower importance).

Examples of criteria for the evaluation of environmental impacts are: extent of traffic impact (prime importance), safety design concepts (moderate importance), and quality and quantity of residue (lower importance).

Examples of criteria for evaluating the qualifications and management plan are: previous experience and performance (prime importance), compliance with RFP conditions (moderate

*The 128 WRRC Technical Committee, the Commonwealth of Massachusetts, and The MITRE Corporation. Request for Proposals, August 1978, p.53. 
importance), and construction schedule (lower importance).

Examples of criteria for cost and pricing proposals are: net tipping fee [oost to communities to dispose at the facility exclusive of transportation costs and less any revenues returned to communities] (prime importance), cost escalation limitations (moderate importance), and financial reporting and auditing procedures (lower importance).*

Following the evaluation, a recommendation will be made to the full 128 WRRC. If there is more than one contractor with similarly high qualifications, the communities themselves may participate in negotiations with these firms prior to a final selection.

When a firm is selected what may be the most difficult aspect of the implementation process begins - signing communities up for longterm contracts (20 years). Local officials can be expected to be naturally cautious when asked to make such a commitment on behalf of their communities to a technology with which most are unfamilar. Long-term contracts between communities and the firm which owns and operates the facility (defined in the draft contract as the Full Service Contractor**) are necessary in order to assure that the

*Ibid pp. $54-56$

**Ibid appendix A. 
conditions of their long-term financing obligations are met.* The following description of the highlights of a proposed contract can serve to give an overall idea of the type of system 128 WRRC expects to procure:

- The Agreement will become effective when the facility has been tested and has met performance requirements as set forth in the construction contract.

- The Contractor will operate and will maintain the facility up to the guaranteed plant capacity for the life of the contract.

- The Contractor will guarantee its contractual obligations under the Operating Agreement.

- The facility is guaranteed to meet all present local, state and federal environmental standards.

- Communities are required to guarantee minimum quantities of solid waste under the Agreement and to pay a fee for such guaranteed tonnage whether delivered or not.

- Each cammunity will set its own minimum

*Robert E. Randol, Resource Recovery Plant Implementation: Guides for Puilic Officials: Risks and Contracts U.S. Environmental Protection Agency Publication S.W.-157.7 1976 p. 39. 
tonnage guarantee after it has been established by the first year's weighing.

- Communities will receive a certain percent of the revenues from the sale of energy and a certain percent of the net revenues from the sale of recovered metals.

- The Agreement guarantees to the communities a minimum energy revenue credit per ton subject to adjustment for changes in the value of energy.

- Communities will share in fees paid by private haulers.

- Capital and operating costs will be based on firm bid prices quoted by the Contractor as of the date of the proposal. Except for inflation(based on an agreed-upon index), certain pass-through costs and legally mandated design or operating changes, any costs for construction and operation of the facility above the bid prices will be absorbed by the contractor.

- Communities have the right of "first refusal" for continuing service at the conlusion of the 20 year term of the Agreement. 
- Communities will have joint representative to monitor the performance of the contractor under the Agreement.

- Communities may continue or establish source separation/recycling programs in accordance with the provisions of the Agreement. *

B. An Evaluation of the 128 WRRC

This section will examine the 128 WRRC using the questions posed at the end of Chapter Four. There will be a discussion of 1. organizational framework, 2. appropriateness of the level of organization, 3. avoidance of the dangers of a single mission authority and, 4. an evaluation in terms of Gross's list of advantages and disadvantages.

1. Organizational Framework

The organizational framework of the 128 WRRC can be viewed as particularly suited to the statuatory distribution of solid waste responsibilities and powers in the Commonwealth of Massachusetts. The responsibility for solid waste disposal lies with each municipality in the Commonwealth.** Because there is no statuatory basis for them, regions mandated by the state are out of the question. Thus, if the economies of scale of a regional project are to be realized, each commity must individually decide to participate. The 128 WRRC

\footnotetext{
*The 128 WRRC, Commonwealth of Massachusetts; and the MITRE Corporation, "Agreement Summary." July 1978.

**Evelyn F. Murphy, Letter to William R. Adams, U.S. EPA Regional Administrator on "Agency Identification" as required by the Resource Conservation and Recovery Act of 1976 dated May 8, 1978. Attached as Appendix .
} 
provides the framework for these communities to implement their decisions on how to approach regional solid waste disposal.

The BSWD is the agency through which the Commonwealth most directly participates in the process. This agency acts as a secretariat in such activities keeping records, arranging meetings, and assisting communications among member communities and with firms bidding on the project. It also provides technical assistance both in-house and through its consultant the MITRE Corporation.

To sum up, the member communities bring with them the statuatory authority to supply theirmunicipal solid wastes over a twenty year period to the project. They determine the approach to solid waste disposal and, by their collective voluntary participation, the extent of the region. The state provides technical assistance and organizational support.

Adequate power does exist on an overall jurisdictional level. However, that power resides in the individual member communities, rather than in some state or regional authority.

\section{Appropriate Level of Organization}

The 128 WRRC can be thought of as a region composed of a number of independent, but cooperating units. The copperation among these communities allows them to avoid the relative high unit costs of solid waste disposal that would otherwise be incurred by each locality acting alone.

The externalities of solid waste disposal are reduced by regionalization in that fewer facilities need be built (it is not unlikely that only one facility will be necessary to serve the needs of the entire 128 WRRC area). A facility could negatively effect both the host 
community and adjacent communities. The host community will be a member of the 128 WRRC and will, as such, have a vice in all decision. Beyond that, the host community is given special rights in Article 10. (d) of the 128 WRRC Bylaws: "Substantive measures directly affecting a host community shall be subject to veto by the sole negative vote of the host community."*

Adjacent communities also are given the opportunity to join the 128 WRRC if they are not already members. A member community has an input into the decision making process and can share in any benefits the project may produce. Thus, to the extent there is a potential for externalities, there is a mechanism for dealing with them: the incorporation of the affected community into the decision-making group. The decision-making group may contain, and is limited to, only those communities who may be, positively or negatively, directly affected by the project.

\section{Avoidance of a Single Mission Authority}

The 128 WRRC avoids the pitfalls of a single mission authority by virtue of its structure It is composed of members representing local units of general government. As such, the ultimate decisionmakers are local officials or town meetings who must weigh decisions regarding approaches to solid waste disposal against all the other priorities a municipality must address.

Rather than short-circuit the political process, as an authority

*128 WRRC Status Report, Appendix A. 
of the type Hudson describes (Chapter III), the approach under discussion subjects regional resource recovery to the political processes of each of its member communities. Rather than stifling local opposition, this approach is based on the local communities making all of the decisions such as siting, selecting an approach to regional solid waste disposal, and selecting a technology and contractor. Preemption of local authority by the state does not become an issue since local government retains its power and responsibility to dispose of municipal solid waste.

4. Summary of the Advantages and Disadvantages of a Delocalized Approach

Gross's list of advantages and disadvantages of a delocalized approach to solid waste disposal was quoted in Chapter III. It is now possible to apply that list to the case of the 128 WRRC.

a. Advantages

(1) Economic - The 128 WRRC will benefit from the economies of scale this regional approach will bring. A regional base will also support the high capital investments needed for a resource recovery system. (2) Environmental - A regional base will support costly equipment for the protection of the environment. A larger land base has allowed the 128 WRRC to select a suitable site.

In addition, a regional system will allow member communities to dispose of solid waste in an environmentally sound, rather than haphazard manner.

(3) Political and Social - Although the private sector has a major role as owner and operator of a resource recovery system, in the 128 WRRC plan, they are only a part of a system which is answerable both to member 
commities and the state. While solid waste disposal will not disappear as a local budget item, local officials will be dealing with a relatively stable price over a twenty year contract period. Facility siting will cease to be an issue for local officials once a regional facility(ies) is in place. In addition, a regional resource recovery system can prevent, acoording to Gross, the encroachment of "organized crime" which is reputed to have taken over large segments of the private solid waste disposal market.

b. Disadvantages

(1) Economic - Gross pointed out the costs associated with implementation may be high if objections to regionlization are raised. In the case of the 128 WRRC ebjections to various aspects of the project, if not to regionalization itself, can cause delàys. After a contractor is selected the process of signing up enough communities to comit sufficient tonnage to begin construction is. likely to be quite time consuming, hence oostly.

Although transfer stations can add to protect costs and transportation costs can be expected to rise, such costs will be more than offset by economies of scale which can be realized with a regional system.

(2) Environmental - While a regional resource recovery system will concentrate the impacts of solid waste disposal, Gross was more concerned with the problems, such as leachate, associated with regional landfills. A resource recovery system is not free of environmental impacts such as air pollution caused by the combustion of refuse and increased local truck traffic. These impacts however, can be weighed against the impacts of alternatives such as a regional landfill or, especially 
a number of local landfills in varying states of cormpliance with environmental regulations.

In regulating the resource recovery system to be used by the 128 WRRC, the state regulatory agencies will not be dealing with a large quasi-independent authority of the type both Gross and Hudson warn against. Instead a private sector contractor will own and operate the system subject to the environmental regulations of the locality(ies) in which the facility(ies) is sited and the state.

(3) Political - Gross's concern that local land use controls would be overridden is obviated by the approach of the 128 WRRC. The 128 WRRC siting process left this issue in the hands of the host and other member communities.

His other political concern, that antagonism between some local govermments and state or regional authorities would be aggravated is minimized since local governments are the ultimate decision makers in the 128 WRRC. However, therewill be, no doubt, some antagonism on the part of some local officials and citizens who may view the 128 WRRC as a creature of the state. In a sense this view is correct in that regional resource recovery groups such as the 128 WRRC are integral components of the state's overall solid waste management strategy. Regional resource recovery systems are promoted by the state to provide alternatives to unsatisfactory conventional disposal facilities. The existence of such an alternative allows state regulators more flexibility in closing down inexpensive but unhealthy local facilities thus antagonizing local officials who wish to continue solid waste disposal on the cheap. 
(4) Social - A large regional authority is likely to be less open to public participation in making solid waste disposal and land use decisions. As can be seen from the foregoing discussion, the 128 WRRC approach is an attempt to maximize - the participation of local officials and interested members of the general public. C. Criticism of the Commonwealth of Massachusetts Approach The Obstacles to Regional Resource Recovery: A Massachusetts Case Study by Larry Susskind and Richard Newcome was published in December, 1977 as a part of the Massachusetts Institute of Technology's Environmental Impact Assessment Project. The study focused on the Northeastern Massachusetts Resource Recovery Project to "... document the technical and institutional obstacles to regionalization of resource recovery and to suggest strategies for overcoming existing barriers."* Susskind and Newcome found that following questions to be especially important:

(1) What role should state government play in enabling regionalization of solid waste management? (2) To what extent are local officials capable of handling the technical issues involved in choosing a resource recovery technology, selecting a site for a regional facility, and negotiating with the private contractors who build and operate resource recovery plants? (3) What sort of bargaining process is needed to ensure equitable and efficient consideration of the environmental, financial, and political concerns of the parties involved in any regional resource recovery project. **

\footnotetext{
*The Obstacles to Regional Resource Recovery ... p.3
} 
1. The Role of the State

Susskind and Newcome propose three models of state involvement, all of which assume that the problem is of more than local concern. The first, "Strong State Intervention", has the state specifing regional boundaries, becoming directly involved in project financing, making regional disposal of municipal solid waste mandatory, and either siting facilities through the direct exercise of eminent domain or the authorization of regions: to use this method. *

In states where the above method is politically unacceptable, "Limited State Intervention"is a possibility. Under this approach the state would empower counties or communities to form regional districts, encouraged to do so, perhaps, by state incentives. The regions would not necessarily have taxing power. They might, however, issue bonds and have the ability to negotiate with communities regarding compensation for hosting the plant. This approach, according to Susskind and Newcome, would not require the state to assume any long-term risks in financing new facilities** Both this and the first approach would not require that the state have a particular policy regarding the technology to be used.***

Susskind and Newoome feel that Massachusetts is following a third approach, "Indirect State Involvement", in which it is assumed that the state has no right to force localities to participate in regional solutions. Here the state does not provide financing and land-taking powers remain with local government. They also assert that in this approach state agency

\footnotetext{
*Ibid, p. 53

** It is not made clear who would assume the long-term risks under this approach. $\star \star \star$ Ibid, pp. 53-54
} 
officials "...are anxious to provide technical assistance as an indirect means of influencing local colaboration."*

It is felt by these authors that Massachusetts officials have a specific technological approach to solid waste disposal and that the BSWD "...tilts state technical assistance in a particular direction.

While the BSWD denies it, it appears to us that once the state and its consultants become involved, the question is no longer which management (including low-technology possibilities) might make the most sense for a particular region. The prediliction for a particular solution is not necessarily wrong (in northeastern Massachusetts the state has endorsed a large-scale -- 3000 TPD [tons per day] -- resource recovery[facility] , but localities are being misled if the offer of technical assistance has strings attached. The costs associated with particular waste disposal technologies ought to be considered on a region-by-region basis. At the present time in Massackusetts, it seems to us that inadequate consideration is being given to the full array of costs and benefits in each situation. The state appears to be moving inexorably toward the implementation of its "high" technology plan, although in every case localities will decide whether or not to participate.** 
In William P. Gaughan's (Director of the BSWD) December 1, 1977 letter to Professor Susskind cited earlier, this description of the Massachusetts approach is disputed. Mr. Gaughan feels that while none of the models exactly describe the Commonwealth's approach, the second, "Iimited State Intervention" is somewhat more accurate than the third. In addition, he takes exception to the assertion that the state is attempting to influence local communities to adopt a particular technological approach:

That is in no way true. The approach selected in the Northeast Project was selected by those communities' representatives not the state. The state is not following that approach in other areas. One need only to look at the other projects which we are sponsoring to see that same of the technical assistance we are providing is looking at and evaluating approaches, including low technology possibilities... A fundamental problem of why this misunderstanding [of the state's approach] exists is that this stidy was limited to one situation in which a specific approach has been selected by the communities involved and which the Bureau of Solid Waste Disposal is aiding in implementation. To say that the same approach is being implemented statewide is an ill-informed extrapolation from a limited study.*

\footnotetext{
*Letter to Professor Susskind
} 
Susskind and Newcome in fact have not substantiated their assertion that the state is attempting to impose a particular approach throughout Massachusetts. It does not appear this follows from the facts documented in the case study (which on the whole, seems reasonably accurate). Nor do the authors suggest why the state would want to pursue surh a policy. In fact, the State Solid Waste Plan of September, 1977,(p.20) specifically states: "The selection of a particular technology and scale of operation is dependent upon a number of factors which are specific to individual location or regions."

\section{Iocal Technical Capacity}

Susskind and Newcome criticized the Commonwealth for not adequately preparing local officials to make difficult technical decisions. Part of this criticism is also aimed at local officials for not being more forceful in challenging the technical judgements of the BSWD and the MITRE Corporation. Also, in their opinion, the environmental impact analyses could, on the one hand, have been done more precisely and on the other been packaged for relatively easy public consumption. Finally, they feel that opponents of the project were able to mount effective opposition, because: "... the process had been more or less sealed off ..." and the technical findings of the BSWD and the Greater Lawrence Solid waste committee (the orfinal name of the regional committee now known as the Northeastem Solid Waste Committee NESWC). "... were vulnerable to charges that deals had been made or adequate study not completed."**

\footnotetext{
*The authors make the exception of one the projects chief opponents, Dr. Gene Grillo (an environmental advisor to the City of Haverhill) who was given a special briefing and had access to all material submitted by bidders. **obstacles Regional Resource Reoovery ... p.62.
} 
The authors feel that a greater effort should have been made to educate local representatives, allowing them to rebut such charges with greater authority.*

Mr. Gaughan's letter refutes these arguments. First, it is, he feels, impossible to make local officials experts in every phase of the project. "They must defer at some point to the expertise of other officials and consultants they know to be impartial." Local representatives were, according to Gaughan, given every opportunity to challange any assumption made by the BSWD and MITRE, and to have those assumptions changed if there were justification. The letter goes on to assert that the BSWD and MITRE did a "state-of-the-art" analysis of all factors and offers to consider any specific recommendations to improve the process. Gaughan states that "... (e) very effort was made to provide all interested parties with as much information as they were willing to absorb".**

The criticism that local officials were not sufficiently prepared to handle the complexities of a project such as the Northeastern Massachusetts Resource Recovery Project appears to be at least in part justified. Certainly, if local officials were more technically expert it would allow them more independence in choosing an approach to solid waste disposal and assessing proposals. As a practical matter, however, there is a limit to the number of areas in which a public official, citizen, or professional person can be informed in great depth. That is why specialists exist. It is the obligation of such specialists

\footnotetext{
*Ibid. pp. 62-63

**Tetter to Professor Susskind.
} 
whose duty it is to work in the public interest either directly such as the staff of the BSWD, or indirectly such as the non-profit MITRE Corporation, to provide technical assistance in a disinterested manner.

The Commonwealth's approach to regional resource recovery was designed to be as open as possible. There are, however, a limited number of the public who are interested in involving tinemselves directly. Among those who are, individuals most often have limited amounts of time and limited technical backgrounds. It is important, nevertheless for the state to continue vigorously pursuing their policy of maximizing the level (both in terms of numbers and quality) of local participation and understanding of the process.

3. The Bargaining Process

There are several aspects of the bargaining process that, according to Susskind and Newcome, should be modified to make it both more equitable and efficient:

a. The number of groups and individuals invited to participate should be expanded to include environmental groups, business interests, abutters, and others who may be directly or indirectly affected or interested. Inclusiveness, they feel, is in the long-run more effective than exclusiveness.

b. The participants in the negotiations should have more to say in specifying the scope and character of the technical analysis, rather than have this process treated as the sole province of technicians and professionals.

c. The Environmental Impact Review Process should be an integral part of the bargaining process rather than "... treated as an after-thefact chore."

d. "More flexible techniques for compensating individuals 
and groups adversely affected by regional facilities probably ought to develop." These compensation costs should be shared on a regional basis." Although the exact compensation due each individual may not be possible to calculate, it would be possible to estimate the social costs borne by various groups. Those groups and individuals not satisfied by various forms of compensation will continue to mount various forms of opposition, butthe amount of sympathy they generate will be severely limited.*

Again, Gaughan rejects the implication that the bargaining process was closed. There was always, he claims, every effort made to encourage the maximum participation both in negotiations and technical evaluation. Gaughan also feels that the recommendation that the Environmental Impact Review process be made a part of the bargaining process, "... was attempted within the limits of the state of the art with regard to environmental analysis and public participation."**

In the case of the 128 WRRC, for example, there is significant opposition to using the Stoughton site among citizens and officials in the neighboring Town of Randolph. Randolph had originally rejected an invitation to join the 128 WRRC. Eventually, however, town officials were apparently convinced that they had more leverage working within the 128 WRRC. They are currently members and are represented by one of the most vocal citizen opponents of the project.

The issue of compensation for individuals or groups adversely impacted by a resource recovery system deserves closer examination.

\footnotetext{
*Obstacles to Regional Resource Recovery pp. 70-72

**Letter to Professor Susskind.
} 
Susskind and Newoome have apparently assumed that such a system will have significant adverse effects upon individuals and groups in the region. What those impacts might be, and the methods to be used to determine an equitable compensation are not specified.

4. Impacts and Compensation

In their study, Assessing the Environmental Impacts of Resource Recovery Facilities, * Craig Miller and Michael B. Bever identify several types of impacts relevent to the assessment of Resource Recovery facilities: air quality, water quality, land use, traffic terrestrial and aquatic biology, aesthetics, net energy efficiercy. iesidue, and materials efficiency

In the Draft Environmental Impact Report on the Northeastern Massachusetts Resource Recovery Project each of these areas is examined. The report shows the proposed project to be clearly a better choice than a no action alternative (see chart p. 68'). Of the probable impacts listed four are considered adverse: emissions to atmosphere, increased truck traffic, visual impact, and potential leachate production from residue disposal.**

The Environmental Impact Report makes the case thit thesn atverse impacts can be controlled so as to make their effects negligible There are a number of reasons for this such as:l. such a facility produces energy displacing an equivalent amount of energy which would otherwise be produced by a conventional fossil fuel plant, 2 . there are significant environmental impacts associated with the no action option, and 3. appropriate pollution control devices will keep such impacts as air pollution

*Environmental Assessment Project, Laboratory of Architecture and Planning, Massachusetts Institute of Technology, June 1978.

**Draft Environmental Impact Report... p. 280 : 
SUMMARY OF BENEFICIAL AND ADVERSE IMPACTS OF PROPOSED PROJECT VERSUS NO ACTION ALTERNATIVE

\begin{tabular}{|c|c|c|c|}
\hline \multicolumn{2}{|c|}{ Proposed Project } & \multicolumn{2}{|c|}{ No Action Alternative } \\
\hline Benefictal Impacts & Adverse Impacts & Benefictal Impacts & Adverse Impacts \\
\hline $\begin{array}{l}\text { - recovers energy and materials } \\
\text { - lower overall energy demand } \\
\text { - minimum land requirement } \\
\text { - elminates dependence upon } \\
\text { landfill } \\
\text { - lower overall environmental } \\
\text { impact } \\
\text { - minimum potential of water } \\
\text { pollution } \\
\text { - rellable system with redundancy } \\
\text { and back-up } \\
\text { - dumping indoors } \\
\text { - centralized operation } \\
\text { - sterile final residue } \\
\text { - operates independent of weather } \\
\text { conditions } \\
\text { - provides for economic disposal } \\
\text { - minimizes health hazard from air- } \\
\text { borne micro-organisms } \\
\text { - efficient refuse transport } \\
\text { through use of transfer stations }\end{array}$ & $\begin{array}{l}\text { - emissions to atmosphere } \\
\text { - increased truck traffic } \\
\text { - visual impact } \\
\text { - potential leachate production } \\
\text { from residue disposal }\end{array}$ & $\begin{array}{l}\text { - low a tmospheric emissions at } \\
\text { remote landfflils } \\
\text { - retention of local autonomy }\end{array}$ & $\begin{array}{l}\text { - large land requirement } \\
\text { - extensive ground and surface } \\
\text { water pollution } \\
\text { - creation of odors and potential } \\
\text { explosions } \\
\text { - potential for rodents and vector } \\
\text { problems } \\
\text { - dumping outdoors (noise, unsight- } \\
\text { Iiness) } \\
\text { - political difficulities } \\
\text { - difficulties of expansion } \\
\text { - potential fire hazard } \\
\text { - heavy local truck traffic } \\
\text { - Inefficient use of equipment and } \\
\text { personnel in refuse transport and } \\
\text { disposal }\end{array}$ \\
\hline
\end{tabular}

From: Draft Environmental Impact Report on the Northeastern Massachusetts Resource Recovery Project, June 1978, p. 280 
and noise only marginally higher than ambient levels.

Appropriate siting can keep impacts on abutters to a minimum, By locating resource recovery facilities in industrial arears, aesthetic impacts are reduced. Traffic problems caused by trucks serving the facility are minimized by siting near major highways with direct access to those arteries. In both the 128 WRRC proposed site in Stoughton and the NESWC site in North Andover these conditions are met and so impacts on abutters can be expected to be minimal.

It is possible to make a case that a major impact of a resource recovery facility is psychological. Gross quotes a study which found that in the case of landfills, a "... person's disposition to approve the proposed landfill is related to his beliefs about its consequences..." The study found these beliefs often were not changed by factual evidence. There was noted an inability "...to truly convert a person whose attitude is emotionally anchored."*

Susskind and Newcome themselves quote one other major opponents of the Haverhill site, Representative Francis J. Bevilaqua, as claiming such a plant would bring "rats as as big as dogs" to the city.** Such an emotional statement has nothing to do with a well operated solid waste disposal facility but is often typical of what the public believes.

One should not uncritically accept the conclusions of the Draft Environmental Impact Report. However, it does call to question what, if any, of the impacts of these facilities need to be compensated for, to whom should compensation go, and by what formula(s) should the kind and

*J. R. Sheaffer, G. S. Tolley, Z. Preewinkle, J. Havlicek, Jr., G. Davis, Y. Wang, H. Bonus, F. L. Strodtbeck, B. Madsen, C. Haller, and R. Bulatao. Decision Making and Solid Waste Disposal. Center for Urban Studies, University of Chicago, Chicago, 1971. Quoted in Issues in the Regionalization of Solid Waste Management Planning, p. 116

**The Obstacles to Regional Resource Recovery... p. 37 
amount of compensation be determined.

Studies such as " 'Not or my Block You Don't': Facility Siting and the Strategic Importance of Compensation" by Michael O'Hare* have examined compensation as a tool for siting what he refers to as "locally noxious facilities." O'Hareis concerned with facilities which are "perceived (ny emphasis) as locally noxious: noisy (airport), smelly (solid waste recycling), ugly (oil refinery), scary (prison), or otherwise disagreeable to its immediate neighbors."**

O'Hare seems to be as much concerned with perceived as actual impacts. (He does not support with any evidence the assertion that solid waste recycling is smelly. Open dumps and poorly run landfills are smelly. Clearly, this is a case of guilt by association.) It is his contention "...that compensation for local sufferers is not only an equitable desideratum, as has long been recognized, but a strategic necessity for aligning critical actors' interests with the public interest."*** Thus, compensation should be considered for use as a method for overcoming opposition to facilities regardless of their actual impacts, zccording to O'Hare.

A study by Brian C. Mellea, of regional resource recovery committees also stressed the importance of compensation as an aid to siting resource recovery plants. Mellea makes the assumption that there will be adversely affected abutters. He suggest that compensation could include money, extra votes on the committee, control over truck routing or plant operation and that the amount of money given to the host community in lieu of taxes

*Public Policy, Volume 25, No. 4 (Fall 1977) pp. 407-458.

$\star \star$ Ibid, p. 409 .

***Ibid, p. 414 
be exactly specified. NESWC is cited as an example of a committee which has made such a specification. The amount, according to Mellea, should be specified so that communities can better weigh hosting oosts against benefits.*

The Commonwealth of rassachusetts provides compensation to host communities through a one dollar fee in lieu of taxes, to be paid by the private operator of a resource recovery facility.** State law establishes payment as that amount, therefore, any change. in the compensation formula would have to come through legislative action. Since the one dollar per ton fee is an operating expense the private contractor passes on to each member community, there are more communities which would stand to lose from an increase in the fee than would gain, making the enactment of such legislation unlikely.

In examining the Massachusetts approach to compensation it can be assumed that there would be two general reasons for providing it: 1 . there is a moral obligation to compensate communities and individuals who may be in some way affected by a facility, and 2. compensation can be useful in gaining public acceptance for a facility. In the first case, it has yet to be established who would be injured, to what extent, and what an equitable payment should be. If the fear of the impacts of a resource recovery facility is based upon erroneous perceptions, the type and amount of compensation becomes even more problematical. In the case of the host conmunities of North Andover (NESWC) and Stoughton

\footnotetext{
*Brian C. Mellea, The Effectiveness of Regional Committees in Implementing Regional Resource Recovery Programs. Environmental Impact Assessment Project, Laboratory of Architecture and Planning, Massachusetts Institute of Technology, February 1978.

**Chapter 16, Section 24A of the General Laws of Massachusetts.
} 
(128 WRRC), it appears that the fee, host community veto, and control of

such items as truck traffic patterns, has been sufficient to gain political acceptance for the facility, making additional forms of compensation, so far, unnecessary.

It should not be assumed that political acceptance will remain stable over time. NESWC's experience with the shifting attitudes in Haverhill regarding their host status should disabuse one of that idea. In the case of the 128 WRRC's Stoughton site, political acceptance appears to be solid. The project however, is not without local opponents. There is a group within Stoughton who have put an anti-resource recovery referendum on the ballot. There is also the very real threat of an attempt by the neighboring Town of Randolph to block the construction of a resource recovery system by legal means.

Some of the studies cited in this section have assumed, a priori, that a resource recovery plant is a nuisance facility with specific negative impacts that should be compensated for. Before a system of compensation is adopted, however, further study should explore the nature of the impacts, who they hurt, and specifically how compensation should be used (or whether it need not be used) to ameliorate their effects.

Current Massachusetts projects, such as the 128 WRRC, have the flexibility to respond to specific situations in which some form of special consideration or compensation might be called for to facilitate public acceptance. While the amount of financial compensation to the host conmunity is set by law, regional groups can make necessary accommodations to affected groups, individuals, or municipalities on a case by case basis. 
Chapter V

Conclusions

I. The Massachusetts Approach

Although the intention of the Massachusetts Legislature in rejecting mandatory regionalization may have been primarily the protection of home rule perogatives, that action, in the long run, may work to the benefit of regional resource recovery in the state. As discussed earlier in this paper, there are disadvantages to the state preempting local solid waste disposal authority which are avoided by encouraging local governments to form voluntary regional solid waste management organizations. However, this approach is not without drawbacks.

One of the most difficult problems organizations such as the 128 WRRC have to overcome will be convincing the leaders of their respective communities to commit their municipalities to twenty year contracts. If the experience to date of NESWC is any indication, communities will be reluctant to be the first to sign these long-term agreements. Up until that point decisions are made by representatives to the regional committee. Even difficult decisions such as siting and choice of contractor can be settled by a committee. Even though siting will involve political decisions on the part of a few member communities, only one or two towns need agree to accept host status. The actual commitment to long-term contracts will involve separate political decisions in each of the member towns.

It may for instance, be decided that 1,500 tons per day of municipal solid waste must be committed before a facility can be constructed. That may involve a commitment on the part of as many as twenty or thirty localities. 
This can be expected to take a good deal of time and persuasive effort on the part of the regional committee and their sponsors in the Bureau of Solid Waste Disposal. This difficulty appears to be inherent in an approach predicated on local home rule.

Another difficulty with the approach is that localities which delay in making a decision to comit their solid waste to a regional facility may find themselves out in the cold. A system will be constructed to serve a limited amount of solid waste tonnage. This amount will be less than the total potential tonnage of the region since it is assumed that some localities will be slow to commit themselves to the facility. In order to begin construction in a reasonable amount of time, a minimum amount of tonnage will be specified. When that amount is signed-up it will trigger ground breaking. Thus, the coverage of voluntary regionalism can be spotty. Again, the problem of incomplete coverage is inherent in an approach which depends upon a great many separate political decisions being made.

The complexity of a resource recovery project, not only in purely technical terms, but also in terms of financial, contractual, and institutional considerations make regional resource recovery systems a quite difficult issue for local government to deal with. The need for local officials to rely on expert advice in such matters is not unusual since many of the issues they deal with have technical demensions beyond their expertise. Local officials need not be experts in solid waste disposal nor, indeed, in education, zighway maintenance, or any other aspect of local government in order to make sound decisionsbased upon expert advice. What is necessary is that a regional committee, and, if they wish 
local communities obtain competent and disinterested consultants to give them such advice.

Even though there are a number of problems involved with the Massachusetts approach to regional solid waste disposal, its advantages justify its use. It allows each local community maximum freedom to choose how it will dispose of its waste (given the increasing enforcementeffort of the DEQE) . At the same time it allows each community to share the advantages a regional resource recovery system can offer, without imposing the disadvantages posed by mandatory regions controlled by state or regional authorities. Siting, as in the 128 WRRC experience, becomes a self-selection process when one or more localities recognize the advantages of host status can outweigh any disadvantages. Thus, siting is not a matter of the imposition of an unwanted facility by an external authority, but an act by a potential host community in its own self-interest.

The Massachusetts approach to regional resource recovery is one which emerged from the particular political context of the state. Counties are vestigial. Regional planning agencies (RPA's) are without implemention powers, (although several of them have served usefur roles in assisting regional committees by providing data and helping with pubic participation). In the case of both counties and RPA's , their boundaries are not necessarily congruent with a politically, or economically optimal region. This leaves the state and the local governments as primary actors in defining regions for the purposes of resource recovery.

As was related in Chapter II, the attempt to impose mandatory regions on the state failed. The reason for this failure was, primarily, the political power of home rule in Massachusetts. This forced state 
officials to formulate a new approach to regional resource recovery based upon the responsibility of each municipality of the state to dispose of their own solid waste. While there are the inherent difficulties in this approach that are discussed in this chapter, there is reason to believe that they are outweighed by its advantages, which include:

- Greater flexibility to respond to the needs of each of the region's member communities. This responsiveness is related to the fact that member communities collectively make the ultimate decisions.

- Siting is facilitated by having member communities propose potential sites.

- Decisions are made by officials who are responsible for all phases of local government. Thus, potential excesses of single purpose authorities are avoided.

- The approach is open and inclusive. All who expect either to benefit or be harmed by a project can be represented in the decision-making process.

\section{B. Recommendations}

The recommendations of this section do not propose major shifts in state policy. Such shifts could be expected to be politically difficult, if at all possible, and to have dubious practical results. Rather, these recommendations point to areas of the state approach which receive special attention as the attempt to implement regional projects proceed.

One of the most important tasks that advocates of regional projects have is to persuade local officials that the long-term interests of their communuties will be well served through a regional resource recovery system. A major impediment in making this case is the limited amount of practical 
experience in this field. Although there is a successfully operating facility in Saugus Massachusetts, none of the state sponsored projects has as yet broken ground. It will be important for officials of the BSWD and individuals who participate in the regional groups to make a convincing case for these projects to the member communities. Increasing regulatory pressure on the part of the DEQE can be expected and this too should help to induce communities to favorably consider an alternative that promises to deliver, at a relatively low and stable cost, an environmentally acceptable means of disposing of municipal solid wastes.

Unless it can be shown in future studies that there are significant negative impacts on abutters of a resource recovery facility, the issue of compensation will remain a problematical one. So far, the one dollar per ton payment to host communities and the special weight their voices: carry in making decisions regarding the project, appear to be sufficient to secure political acceptability. In the absence of evidence that particular harm is caused to abutters assuming the facility is well sited, also assuming the community as a whole benefits from the facility, then it can be assumed that equity considerations have been met.

If the regional decision-making process remains open, it can be a more flexible, effective, equitable tool than a predetermined formula for compensation. Thus, it is important that potentially affected individuals, groups, and units of government retain access to this process. 
$\underline{\text { References Cited }}$

Bryson, John E. "Solid Waste and Resource Recovery" in Federal Envirommental Law ed. Erica L. Dolgin and Thomas G. P. Guilbert. St. Paul, West Publishing Co. 1974.

Commonwealth of Massachusetts, Acts of 1973, Chapter 1217, Section 21. Chapter 16, Section 2A, General Laws of Massachusetts. House of Representatives, \#6643, May 14, 1973. Solid Waste Management Plan. November 1975. State Solid Waste Management Plan, Summary

Report. C. 1972 State Solid Waste Plan, September 30, 1977. Bureau of Solid Waste Disposal and the MITRE Corporation, 128 West Resource Recovery Council Status Report, January, 1978. Cousins, Alden, Personal Communication, September, 1978. Gaughan, William P. Letter to Professor Susskind, December, 1977.

Gilbert, Jane. Efforts at Intermunicipal Cooperation for Solid Waste. RSRI Discussion Paper Series: No. 68, Philadelphia, Regional Science Institute, October, 1973.

Gross, Frederick P. Issues in the Regionalization of Solid Waste Management Planning. Report R 75-26, Cambridge, MA; Massachusetts Institute of Technology, 1975.

Hudson, James F. "The Need for Continued Local Control Over Solid Waste Management", Unpublished Paper, Massachusetts Institute of Technology, 1973.

Levey, Steven J. and Gregor H. Rigo, Resource Recovery Plant Implementation: Guides for Municipal Officials: Technologies, (SW-157-2) Washington D.C. U.S. Environmental Protection Agency, 1976.

Lewis, Steven G. "Regionalism: Its Role in Resource Recovery" in Proceedings of the Fifth National Congress in Waste Management Technology and Resource and Energy Recovery, Washington, D.C., U.S. Environmental Protection Agency, 1977. 
Mellea, Brain C. The Effectiveness of Regional Comittees in Implementing Regional Resource Recovery Programs. Environmental Impact Assessment Project, Laboratory of Architecture and Planning, Massachusetts Institute of Technology, February 1978.

Miller, Craig and Michael B. Bever. Assessing the Environmental Impacts of Resource Recovery Facilities. Environmental Assessment Project Laboratory of Architecture and Planning, Massachusetts Institute of Technology, June 1978.

Murphy, Evelyn F. Letter to William R. Adams, U.S. EPA Regional Administrator on "Agency Identification" May 8, 1978.

O'Hare, Michael. "Not on My Block You Don't': Facility Siting and the Strategic Importance of Compensation." Public Policy, Vol. 25, No. 4 (Fall 1977).

The 128 WRRC, Commonwealth of Massachusetts and the MITRE Corporation. "Agreement Summary."July, 1978.

The 128 WRRC Technical Committee, Commonwealth of Massachusetts, and the MITRE Corporation. "Project Description" Sumary of RFP, July, 1978.

Request for Pronosals, August, 1978.

Randol, Robert E. Resource Recovery Plant Implementation: Guides for Public Officials: Risks and Contracts, U.S. Environmental Protection Agency Publication SW-157.7, 1976.

Raytheon Service Company. Study of Solid Waste Disposal for Program Plan Development for the Commonwealth of Massachusetts, Burlington, MA May 15, 1972.

Resource Conservation and Recovery Act of 1976 Public Law 94-580

Shanley, Robert A. "Local. Political Systems in Relation to Regionalization" in Proceedings of Regionalized Solid Waste Management, Ed. Ruth Kreplick et al, Technical Guidance Center for Environmental Quality, Cooperative Extension Service, University of Massachusetts at Amherst, 1972.

Sheafer, J.R. et al. Decision Making and Solid Waste Disposal. Center for Urban Studies University of Chicago, Chicago, 1971.

Stone, Martha. Personal Communication, July 1978.

Susskind, Lawrence and Richard Newcome. The Obstacles to Regional Resource Recovery: A Massachusetts Case Study. Environmental Impact Assessment Project, Laboratory of Architecture and Planning, Massachusetts Institute of Technology, December, 1977. 
Toftner, Richard O. and Robert M. Clark. Intergovernmental Approaches to Solid Waste Management, Forward by Richard D. Vaughan, Report \#SW-47ts, Washington D.C., U.S. Enviromental Protection Agency, 1971.

U.S. Environmental Protection Agency. Resource Recovery and Waste Reduction Fourth Report to Congress. EPA publication SW-600 Washington, U.S. Government printing office, 1977. 